\title{
НЕКОТОРЫЕ ОСОБЕННОСТИ ПРОТЕОЛИТИЧЕСКОЙ АКТИВНОСТИ КСИЛОТРОФНЫХ МАКРОМИЦЕТОВ
}

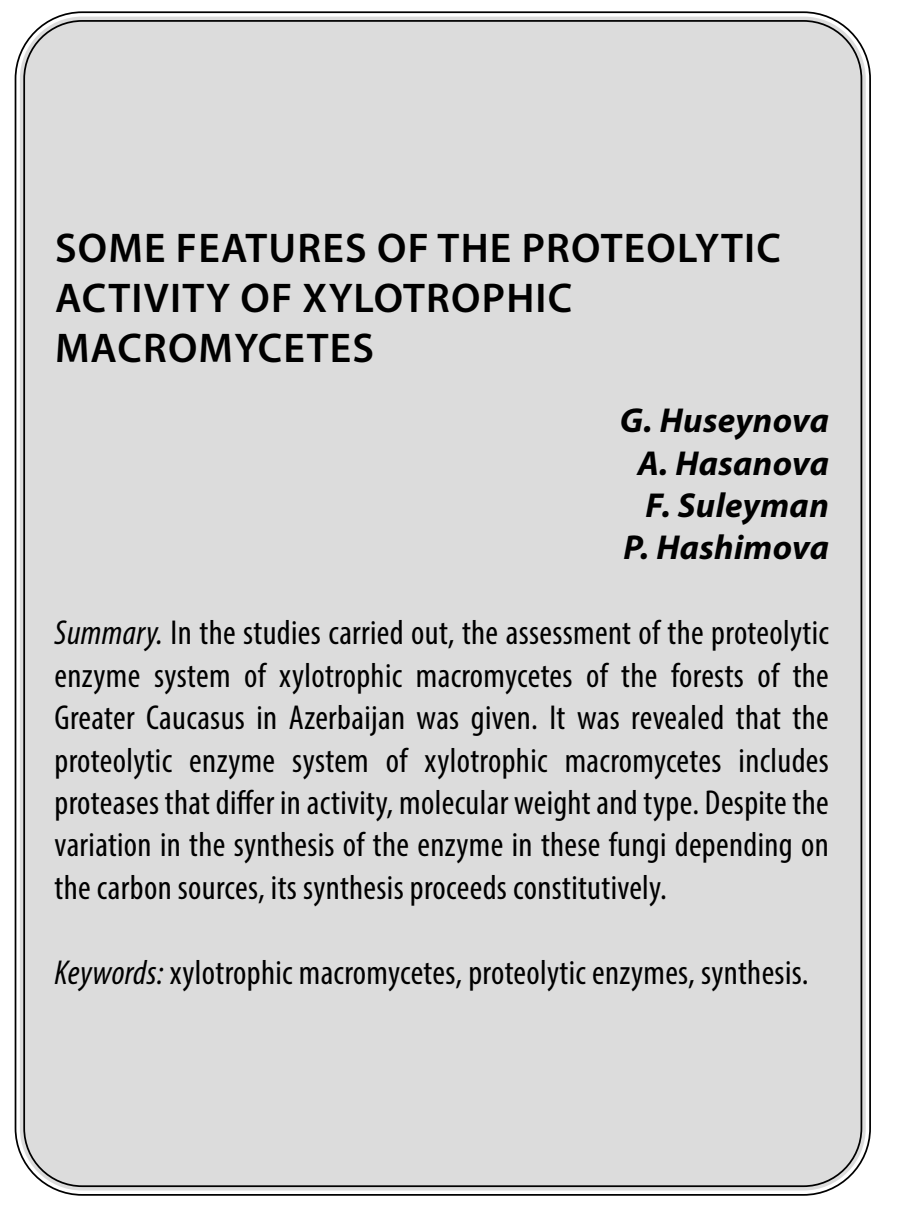

И звестно, что ксилотрофные грибы играют важную роль в структуре растительных биоценозов. Так, эти грибы, имеющие сильную и многообразную ферментную систему, участвуют в деградации сложных полимеров, таких как целлюлоза, лигнин, пектин, гемицеллюлоза и белок, составляющих основу клеточной стенки растений [11]. В связи с этим ксилотрофные грибы привлекают внимание исследователей либо как возможный участник биоконверсии растительных субстратов, либо как продуцент того или иного фермента.

Биодеградация растительных субстратов в естественных условиях представляет собой многоступенчатый и полиферментный процесс, в котором участвуют как гидролазы, так и оксиредуктазы [7, 9]. В результате последовательного действия различных ферментов, выделяемых грибами вне клетки, молекулы субстратов разрушаются и образуются легко усваиваемые и низ-
Гусейнова Гюлнарь Иса гызы

Докторант, Институт Микробиологии НАН

Азербайджана, г. Баку

gulnar_muel@mail.ru

Гасанова Арзу Расул гызы

К.б.н., старший преподаватель, Сумгаитский Государственный Университет, Азербайджанская

Республика, г. Сумгаит

arzu.h85@mail.ru

Сулейман Фарида Махир гызы

Докторант, Институт Микробиологии НАН

Азербайджана, г. Баку

s.feride.96@gmail.com

Гаиимова Парвин Мирдамат гызы

Докторант, Институт Микробиологии НАН

Азербайджана, г. Баку

peri.omar87@gmail.com

Аннотация. В проведенных исследованиях дана оценка протеолитической ферментной системы ксилотрофных макромицетов лесов территории Большого Кавказа в Азербайджане. Выявлено, что протеолитическая ферментная система ксилотрофных макромицетов включает протеазы, различающиеся по активности, молекулярной массе и типу. Несмотря на варьирование синтеза фермента у этих грибов в зависимости от источников углерода, его синтез протекает конститутивно.

Ключевые слова: ксилотрофные макромицеты, протеолитические ферменты, синтез.

комолекулярные олигомеры и мономеры, которые используются грибами для регулирования своего энергетического баланса.

На сегодняшний день исследования ксилотрофных грибов сосредоточены на изучении их целлюлолитической и лигнолотической активности [8, 10, 14, 15], но изучению других ферментов, в том числе протеаз, катализирующих гидролиз белков [2, 12], уделено недостаточное внимание.

Поэтому целью данной статьи является изучение условий, влияющих на синтез протеаз ксилотрофных макромицетов и их внеклеточную секрецию.

Eng. Life Sci. 2018, 18, 768-778

ignocellulose degradation: An overview of fungi and fungal enzymes involved in lignocellulose degradation 
Таблица 1. Протеолитическая активность грибов

\begin{tabular}{|c|c|c|c|c|c|}
\hline \multirow{3}{*}{ Использованные грибы } & \multicolumn{5}{|c|}{ Активность (ед./ml) } \\
\hline & \multicolumn{5}{|c|}{ Срок культивирования (дни) } \\
\hline & 2 & 4 & 6 & 8 & 10 \\
\hline Bjerkandera adusta & 0,46 & 0,62 & 0,68 & 0,70 & 0,60 \\
\hline Cerrena unicolar & 0,35 & 0,50 & 0,56 & 0,59 & 0,56 \\
\hline Fomes fomentarius & 0,42 & 0,60 & 0,67 & 0,65 & 0,60 \\
\hline Fomitopsis pinicola & 0,41 & 0,64 & 0,69 & 0,70 & 0,69 \\
\hline Ganoderma applanatum & 0,23 & 0,38 & 0,52 & 0,64 & 0,61 \\
\hline Laetiporus sulhureus & 0,32 & 0,57 & 0,74 & 0,73 & 0,60 \\
\hline Ganoderma lucidum & 0,30 & 0,48 & 0,66 & 0,72 & 0,58 \\
\hline Inonotus hisbidus & 0,52 & 0,65 & 0,70 & 0,70 & 0,62 \\
\hline Trametes gibbosa & 0,29 & 0,41 & 0,52 & 0,60 & 0,61 \\
\hline Fomitopsis pinicola & 0,37 & 0,53 & 0,60 & 0,61 & 0,56 \\
\hline Pleurotus ostreatus & 0,17 & 0,31 & 0,46 & 0,56 & 0,57 \\
\hline
\end{tabular}

ignocellulose degradation: An overview of fungi and fungal enzymes involved in lignocellulose degradation

ignocellulose degradation: An overview of fungi and fungal enzymes involved in lignocellulose degradation

ignocellulose degradation: An overview of fungi and fungal enzymes involved in lignocellulose degradation

ignocellulose degradation: An overview of fungi and fungal enzymes involved in lignocellulose degradation

ignocellulose degradation: An overview of fungi and fungal enzymes involved in lignocellulose degradation

ignocellulose degradation: An overview of fungi and fungal enzymes involved in lignocellulose degradation

ignocellulose degradation: An overview of fungi and fungal enzymes involved in lignocellulose degradation ignocellulose degradation: An overview of fungi and fungal enzymes involved in lignocellulose degradation

\section{Материалы и метолы}

В ходе работы было использовано 11 видов ксилотрофных макромицетов, выделенных в чистую культуру[3] из плодовых тел грибов, отобранных в 2015-2021 гг. в лесах территории Большого Кавказа в Азербайджане и идентифицированных в соответствии с применяемыми для этой цели определителями [1]. Рабочие культуры хранили при $4{ }^{\circ} \mathrm{C}$ в пробирках с агаризованным солодовым сусло.
Выращивание грибов, изучение влияния питательных веществ на синтез и секрецию протеаз, определение активности протеаз [4] и содержания белка [6], а также частичную характеристику протеаз проводили по известным методам, используемым в работе различных авторов [2, 12].

При изучении влияния ингибиторов для цистеиновых протеаз использовался йодацетамид (ЙАА), для металлопротеаз - этилендиаминтетрауксусной кислоты (ЕДТА), для сериновых протеаз - фенилметилсульфонилфторид (ФМСФ), хлорметилкетон тиозил-L-фениалаланин (XMКТФ) и хлорметилкетон тиозил-L-лизин (ХМКТЛ).

\section{Полученные результаты и их обсужАение}

Результаты исследования внеклеточной протеолитической активности использованных грибов приведены в таблице 1. Как видно, все использованные грибы обладают протеолитической активностью. Для определения этой активности использовали синтетические субстраты (производные трипсина и субтилизина, а также азоказеин и желатин) для двух групп сериновых протеаз.

Среди грибов, у которых изучалась протеолитическая активность, можно выделить грибы, которые секретируют по крайней мере одну или несколько наиболее распространенных групп протеаз, различающихся по активности и молекулярной массе. Так, у грибов F. pinicola, P. ostreatus и L.hisbidus была идентифицирована одна группа протеаз (62 кДа), у B. adusta, G. applanatum и T. Gibbosa - две группы протеаз (85-93 кДа и выше 
Таблица 2. Влияние ингибиторов на активность экзопротеаз ксилоторофных грибов

\begin{tabular}{|c|c|c|c|c|c|c|}
\hline \multirow{2}{*}{ Ингибиторы } & \multirow{2}{*}{ Концентрация, mM } & \multicolumn{5}{|c|}{ Остаточная активность, \% } \\
\hline & & B.adusta & P. ostreatus & G.lucidum & L.sulphureus & T.gibbosa \\
\hline ЕДТА & 10 & 14 & 80 & 43 & 47 & 72 \\
\hline ФМСФ & 1 & 81 & 60 & 60 & 58 & 50 \\
\hline ХMКТФ & 3 & 86 & 100 & 98 & 75 & 98 \\
\hline ХМКТЛ & 2,5 & 93 & 94 & 96 & 83 & 97 \\
\hline
\end{tabular}

95 кДа). Три группы протеаз обнаружены только у гриба G.lucidum, где молекулярная масса первой группы составляет 50 кДа, второй - 70 кДа, третьей - 95 кДа.

Следует отметить, что, в отличие от конкретных используемых синтетических субстратов, которые позволяют точно определять тип протеаз, определение активности непосредственно в гелях позволяет определять общую протеолитическую активность, способную гидролизовать белковые субстраты. Поэтому определение класса протеаз проводили с использованием белковых субстратов в присутствии ингибиторов (таблица 2). Как видно, в исследуемых грибах обнаружены как серин, так -и металло-протеазы, но их пропорции могут варьироваться в зависимости от продуцента. Так, металлопротеиназы гриба B. adusta и сериновые протеазы гриба T. gibbosa имеют относительное преимущество.

Синтез того или иного фермента зависит от генотипа продуцента [5], но его реализация существенно зависит от условий выращивания и состава среды.

Исследования добавления различных источников углерода в среду показали, что для проявления высокого уровня протеолитической активности используемых ксилотрофных грибов использование белковых веществ в качестве источника углерода не носит обязательного характера. Это говорит о том, что ксилотрофные макромицеты в отношении влияния добавления в среду белковых веществ на синтез протеаз отличаются от некоторых фитопатогенных и сапротрофных представителей микромицетов [2]. Однако, использование в качестве источника углерода моносахаридов, особенно добавление в среду фруктозы, приводит к определенному увеличению внеклеточной активности протеазы, но это увеличение не проявляется как повышение активности индуктивного фермента.

Проведенные исследования показали, что рН среды является одним из факторов, существенно влияющих на активность протеаз у ксилотрофных макромицетов. Это более выражено проявляется при изучении общей внеклеточной активности по азоказеину (рис. 1). Как видно, диапазон кислотности среды 5,0-6,5 является благоприятным для активного синтеза протеаз грибами, такая зависимость характерна и для таких представителей микромицетов, как Aspergillus niger, Botrytis cinerea и др. [13].

Таким образом, распространенные в Азербайджане ксилотрофные макромицеты могут активно синтезировать протеолитические ферменты, а их протеолитическая система включает как серин-, так и металло-протеазы.

\section{ЛИТЕРАТУРА}

1. Бондарцева М.А. Определитель грибов России. Порядок афиллофоровые. СП.: Наука, 1998, вып. 2, 391 .

2. Дунаевский Я.Е. и др. Деградация белковых субстратов ксилотрофными базидиомицетами//Микробиология, 2006, т. 75, № 1, с. 46-51.

3. Методы экспериментальной микологии (Под. ред. Билай В.И.) //Киев: Наукова думка, 1982, 500 с.

4. Лабораторный практикум по технологии ферментных препаратов. -М.: Легкая и пищевая промышленность, 1982, $240 \mathrm{c}$.

5. Мурадов П.З. Основы биологической конверсии растительных отходов. Баку: издательство "Наука", 2003, 114с. 1

6. Практикум по биохимии (Под ред. Н.П. Мешковой и С.Е. Северина.). М: МГУ, 1979, 430 с.

7. Решетникова И.А. Деструкция лигнина ксилотрофными макромицетами. М.: Новинтех-Пресс, 1997, $202 c$.

8. Andlar, M., Rezić, T., Marđetko N. et al. Lignocellulose degradation: An overview of fungi and fungal enzymes involved in lignocellulose degradation.// Eng Life Sci., 2018, 18(11), p.768-778.

9. Aro, N., Pakula, T., Penttilä, M. Transcriptional regulation of plant cell wall degradation by filamentous fungi.// FEMS Microbiology Reviews, 2005, v.29, iss. 4, p.719-739

10. Behera, B.C. Sethi, B.K., Mishra R.R. et al. Microbial cellulases — Diversity \& biotechnology with reference to mangrove environment: A review//J Genet Eng Biotechnol.,2017, 15(1), p.197-210. 
11. Choi, J., Kim, K.T., Jeon, J. et al. Fungal plant cell wall-degrading enzyme database: a platform for comparative and evolutionary genomics in fungi and 0omycetes.// BMC Genomics, 2013, 14, S7. https://doi.org/10.1186/1471-2164-14-S5-S7

12. De Souza, P.M., de Assis Bittencourt, M.L, Caprara C.C. A biotechnology perspective of fungal proteases.//Braz J Microbiol., 2015, 46(2), p.337-346

13. Dunayevsky Y.E. et al. Regulation of secretion of extrasellular proteases by filamentous fungus Botrytis cinerea.//J.Russian Phytopathol.Soc., 2001, v.2, N1, p.39-44.

14. Gupta, V.K., Kubicek, Ch.P. Berrin J.-G.et al.Fungal Enzymes for Bio-Products from Sustainable and Waste Biomass/V.K. Gupta,] //Trends in Biochemical Sciences, July 2016, Vol. 41, No. 7, p.633-645

15. Kantharaj, P., Boobalan, B., Sooriamuthu S. et al. Lignocellulose Degrading Enzymes from Fungi and Their Industrial Applications// Int J Cur Res Rev, 2017, v. 9 , iss. 21, p.1-11

(с) Гусейнова Гюлнарь Иса гызы ( gulnar_muel@mail.ru ), Гасанова Арзу Расул гызы ( arzu.h85@mail.ru ),

Сулейман Фарида Махир гызы ( s.feride.96@gmail.com ), Гашимова Парвин Мирдамат гызы ( peri.omar87@gmail.com ).

Журнал «Современная наука: актуальные проблемы теории и практики»

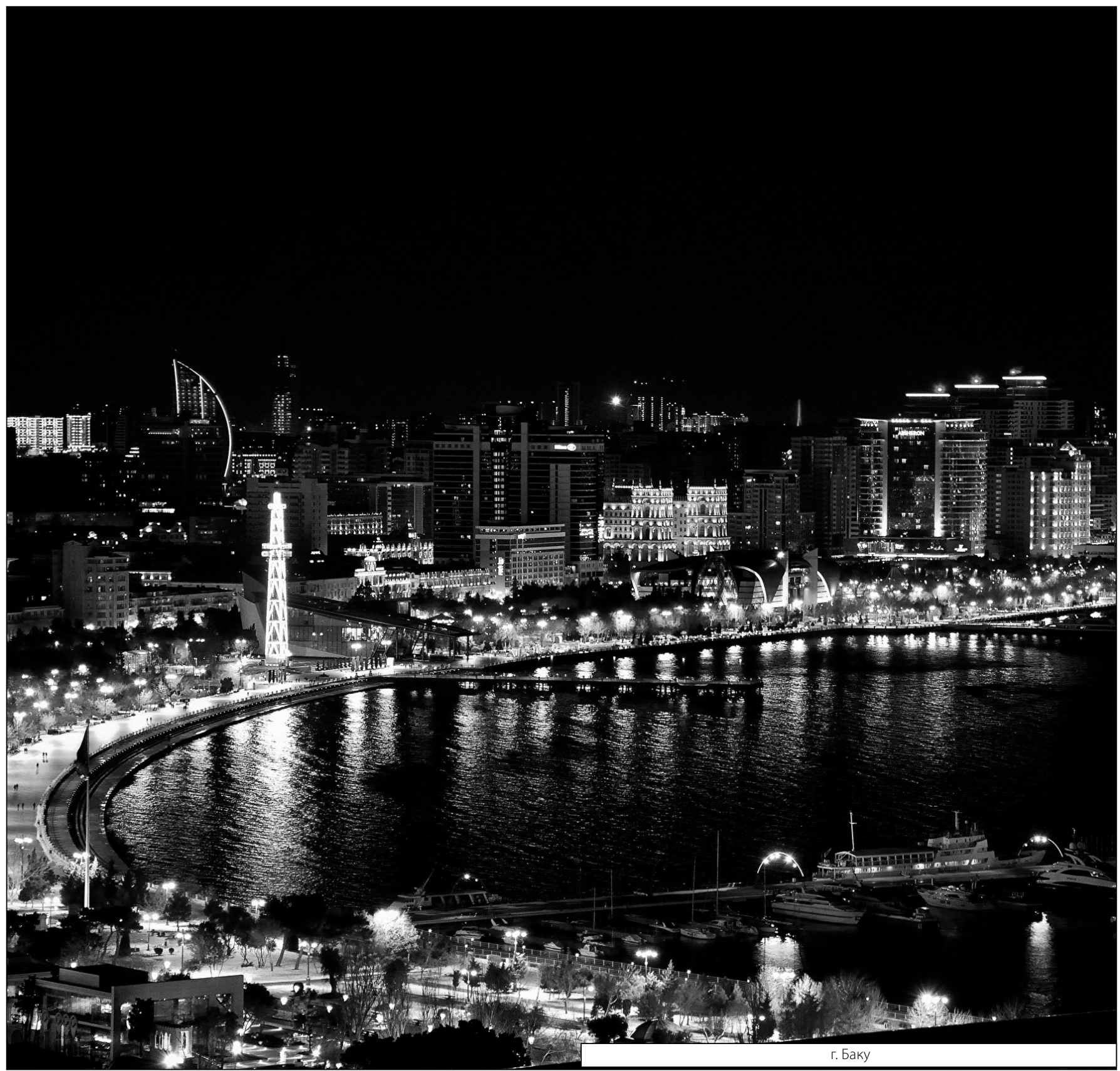

